\title{
Correction to: Crafting anti-corruption agencies' bureaucratic reputation: an uphill battle
}

\section{Nicholas Bautista-Beauchesne ${ }^{1}$}

Published online: 27 March 2021

(c) Springer Nature B.V. 2021

\section{Correction to: Crime, Law and Social Change https://doi.org/10.1007/s10611-020-09928-9}

The original version of this article unfortunately contained mistakes introduced during the production process.

The corrections are given in the following list:

(1) In article title, "Battle" should be "battle".

(2) In "Bureaucratic reputation and anti-corruption" section, fifth paragraph, first sentence, a new reference citation should be added at the end of the sentence as follows:

Hence, this article aims at better understanding ACAs as independent and autonomous agencies through the lens of their bureaucratic reputations - offering a unique window into their post-delegation dynamics [16, 51].

And the new reference is:

51. Tomic, S. (2019). Leadership, institutions \& enforcement: Anti-corruption agencies in Serbia, Croatia and Macedonia. Cham, Switzerland: Palgrave Macmillan.

\section{The online version of the original article can be found at https://doi.org/10.1007/s10611-020-09928-9}

Nicholas Bautista-Beauchesne

nicholas.bautista-beauchesne@enap.ca

1 École Nationale d'Administration Publique, 4750, Avenue Henri-Julien, bureau 5092, Montréal, Québec H2T 3E5, Canada 


\section{(3) In Table 1, "Relevance for Anti-Corruption Agencies" should not be in bold. The correct Table 1 is now given below:}

Table 1 Dimensions of the bureaucratic reputation of ACAs

\begin{tabular}{|c|c|}
\hline Reputational dimension & Relevance for Anti-Corruption Agencies \\
\hline Performative & $\begin{array}{l}\text { Projecting an image of effectively implementing anti-corruption } \\
\text { policies. Achieving repressive outputs such as cases, arrests, } \\
\text { investigations. Achieving preventive outputs such as training, edu- } \\
\text { cation, audits, risk management. Sustaining positive performance } \\
\text { indicators over time, with the ability of pursuing corruption at } \\
\text { all levels of society by creating innovative programs and policy } \\
\text { solutions. }\end{array}$ \\
\hline Moral & $\begin{array}{l}\text { Displaying anti-corruption values such as integrity and honesty; } \\
\text { cultivating norms of transparency, encouraging awareness, best } \\
\text { practices, and ethical behavior. }\end{array}$ \\
\hline Technical-Professional & $\begin{array}{l}\text { Projecting an image of a competent staff which can maneuver the } \\
\text { highly complex corruption environment and cases (i.e. legal, } \\
\text { financial, criminological etc.); with the ability to deal with the } \\
\text { inherent uncertainty of corruption (i.e. measuring impacts, per- } \\
\text { ceptions, corruption levels). }\end{array}$ \\
\hline Procedural & $\begin{array}{l}\text { Appropriately following legal dispositions despite multiple jurisdic- } \\
\text { tional and judicial hurdles; adhering to investigative and policing } \\
\text { procedures regardless of the complexity of fighting corruption. } \\
\text { Projecting a procedural even-handedness between cases regard- } \\
\text { less of political affiliation. }\end{array}$ \\
\hline Main Audiences & Relevance for Anti-Corruption Agencies \\
\hline The Political Sphere & $\begin{array}{l}\text { Political actors and legislators are a critical audience to convince of } \\
\text { institutional usefulness; they are essential account-holders which } \\
\text { can modify the terms of delegation and discretionary processes: } \\
\text { powers, budget, human/financial resources. High reputational } \\
\text { stakes and intense accountability relationship. }\end{array}$ \\
\hline The Media & $\begin{array}{l}\text { Crucial audience in which to craft the ACA's organisational image } \\
\text { and convince external audiences of successful outputs; Critical } \\
\text { forum in which an agency's credibility can be crafted or hindered. }\end{array}$ \\
\hline Citizens & $\begin{array}{l}\text { Critical audience to change norms and opinions about corruption; } \\
\text { essential source of whistleblower information and witness testi- } \\
\text { monies in court, as well as anti-corruption activism. }\end{array}$ \\
\hline Bureaucratic Agencies & $\begin{array}{l}\text { Very important audience to craft institutional relations and inter- } \\
\text { agency collaboration. Facilitates cooperation between agencies for } \\
\text { cases, information-sharing or coordinating regulatory capabilities. }\end{array}$ \\
\hline The Private Sector & $\begin{array}{l}\text { Important audience to change business norms, encourage coopera- } \\
\text { tion from private firms, incite whistleblowing for witness testimo- } \\
\text { nies or to report irregularities. }\end{array}$ \\
\hline International Actors and NGOs & $\begin{array}{l}\text { Frequently important audience to increase international ties with } \\
\text { other global NGOs, judicial actors, governments or international } \\
\text { police networks for information sharing and jurisdictional coor- } \\
\text { dination. }\end{array}$ \\
\hline Main regulated audiences & $\begin{array}{l}\text { Public servants, private firms, business actors, politicians and } \\
\text { potential corrupt individuals (both corruptor and corrupted). }\end{array}$ \\
\hline
\end{tabular}


(4) In "Conclusion" section, sixth paragraph, last sentence, citation for Table 3 should be deleted. The sentence should be rewritten as follows:

This may prove critical for the morally charged mandates of anti-corruption institutions as they grapple to fight an increasingly complex criminal phenomenon, while trying to win over and maintain public trust.

(5) In the pdf version, the layout of the Table under "Qualitative coding scheme" section was incorrect. The correct Table is now given below:

\begin{tabular}{|c|c|}
\hline Name of node & Description \\
\hline Bureaucratic Autonomy & $\begin{array}{l}\text { General statements which refer to the ability of the ACA to pursue } \\
\text { its mandates without exogenous interference }\end{array}$ \\
\hline (A) Capacities-unique-niche & $\begin{array}{l}\text { Specific statements which pertain to the powers, capacities, pro- } \\
\text { grams which define the autonomy of the agency }\end{array}$ \\
\hline (A) Legitimacy-Network & $\begin{array}{l}\text { Specific statements which pertain to the building of institutional } \\
\text { inter-agency networks and legitimacy that define the ACA's } \\
\text { autonomy }\end{array}$ \\
\hline (A) Preferences-independence & $\begin{array}{l}\text { Specific statements which pertain to the political independence and } \\
\text { organisational preferences of the agency. }\end{array}$ \\
\hline Bureaucratic Reputation & $\begin{array}{l}\text { General statements which refer to the organisational reputation and } \\
\text { credibility of the agency. }\end{array}$ \\
\hline (R) Moral & $\begin{array}{l}\text { Specific statements which pertain to the values and normative } \\
\text { dimension of the ACA's reputation }\end{array}$ \\
\hline (R) Performance & $\begin{array}{l}\text { Specific statements which pertain to performance indicators, out- } \\
\text { puts, and goals of the ACA. }\end{array}$ \\
\hline (R) Procedural & $\begin{array}{l}\text { Specific statements which pertain to the following of protocol, } \\
\text { appropriate procedures, legal and judicial guidelines, and jurisdic- } \\
\text { tions. }\end{array}$ \\
\hline (R) Technical and Professional & $\begin{array}{l}\text { Specific statements pertaining to the competence of the ACA's } \\
\text { staff, their professionalism, the development of a unique technical } \\
\text { expertise in fighting corruption. }\end{array}$ \\
\hline Change and evolution of policies & $\begin{array}{l}\text { General statements pertaining to the modifying of the policy envi- } \\
\text { ronment surrounding the ACA, changes in anticorruption laws, or } \\
\text { the addition of new institutions over time. }\end{array}$ \\
\hline Citizens & $\begin{array}{l}\text { General statements pertaining to the relationship with citizens as an } \\
\text { accountability forum, fostering trust, and cooperation (i.e. witness } \\
\text { testimonies). }\end{array}$ \\
\hline Coordination and Cooperation & $\begin{array}{l}\text { General statements pertaining to inter-agency relations with other } \\
\text { bureaucratic agencies, coordination with other public agencies }\end{array}$ \\
\hline Prevention & $\begin{array}{l}\text { General statements pertaining to the different mandates of corrup- } \\
\text { tion prevention such as education, training, raising awareness, } \\
\text { risk-management etc. }\end{array}$ \\
\hline
\end{tabular}

The original article has been corrected.

Publisher's note Springer Nature remains neutral with regard to jurisdictional claims in published maps and institutional affiliations. 